\title{
Bank-Based Financial Development and Economic Growth: Time-Varying Causality Analysis for Egypt
}

\author{
Amira Akl Ahmed ${ }^{1}$ \\ ${ }^{1}$ Department of Economics, Faculty of Commerce, Benha University, Egypt \\ Correspondence: Amira Akl Ahmed, Department of Economics, Faculty of Commerce, Benha University, Fareed \\ Nada Street, Benha, Qalubiya Governorate, Post Code: 13511, Egypt. Tel: 201-205-224-224. E-mail: \\ amira.ahmed@fcom.bu.edu.eg
}

Received: February 4, 2018

Accepted: February 28, 2018

Online Published: March 10, 2018

doi:10.5539/ijef.v10n4p123

URL: https://doi.org/10.5539/ijef.v10n4p123

\begin{abstract}
The bootstrap approach to Toda-Yamamoto (1995) modified causality test is applied in a rolling window of fixed size onto Egyptian data during 1960-2016 to examine time-varying links between economic growth (EG) and bank-based financial development (BBFD). Full sample results indicated the existence of unidirectional causality running from BBFD to EG, however; instability tests revealed the presence of structural breaks. Given the misleading inferences made using the full sample, the rolling window procedure is applied. Bidirectional time-varying causality between EG and BBFD was detected. Reasons behind declining the fraction of credit provided to private business sector to GDP in recent years include, mainly, credit crunch and expansion of credit to the government and partially to economic slowdown. Adoption of fiscal reforms and promotion of innovative financial tools suitable for the needs of small and medium-sized enterprises is highly recommended to enhance the role of banking system in promoting economic growth.
\end{abstract}

Keywords: financial development, economic growth, time-varying causality

\section{Introduction}

The economic policies adopted in Egypt witnessed dramatic changes since 1960s. During 1960s, development policies were based on import substitution, public enterprises, and heavy government intervention in all economic activities. Moreover, banking sector was subjected to substantial financial repression measures whereas the stock exchange (SE) witnessed a remarkable reduction in its activity due to nationalization of industry and the adoption of central planning policies in 1950s. The SE remained dormant until early 1990s. In 1974, Egypt initiated an outward-looking open-door policy. To serve this policy, a banking law number 120 of 1975, that authorised the launch of private and joint venture banks foreign bank branches, was issued. Given the chronic macroeconomic imbalances accompanied by sluggish growth rates, Egypt signed the Economic Reform and Structural Adjustment Programme (ERSAP), with the International Monetary Fund (IMF) and the World Bank (WB) in 1991, in which banking reform was an important component. In 2004, the Central Bank of Egypt (CBE) launched a non-performing loans (NPLs) unit to restructure public banks and to consolidate banking system through mergers and acquisitions. Starting from 2008, adverse global and country-specific shocks hit the Egyptian economy (e.g. the global financial crash in 2008 and series of political tensions started in early 2011). For example, the ratio of public deficit to GDP doubled between 2008 and 2015/2016. It was mainly financed from domestic banks at the expense of credit provided to private business sector. Public domestic debt reached $97 \%$ of GDP in 2015/2016 whereas its external counterpart represented $18 \%$ in the same year. The real GDP growth at factor cost dropped from $3.1 \%$ in the first quarter of 2015/2016 to $1.7 \%$ in the corresponding quarter a year later (Abu-Bader \& Abu-Qarn, 2008; Bolbola et al., 2005; Elsayed, 2013; Herrera \& Youssef, 2013; CBE, 2016; Helmy \& Zaki, 2017; Ahmed \& Naguib, 2018; ECES, 2017).

Conclusions regarding the debate of finance-growth nexus are still inconclusive (for a recent survey, see, Nyasha \& Odhiambo, 2014). This issue is still controversial at current times since almost all countries in the world, including Egypt as mentioned above and as discussed in section 2, are fighting to improve their growth rates, eliminate public deficits and keep the debt to GDP ratio onto a steadily declining path. The rapid and dynamic rate of globalization pushes developing countries to modernize their financial sectors to achieve faster and safer financial transactions (Nyasha, 2014). There are three theoretical arguments regarding the finance-growth nexus. 
According to the finance-led growth, also known as supply-leading hypothesis, causality runs from financial sector development to real sector growth. In contrast, the growth-led finance, also known as demand-leading hypothesis, claims that causality runs in the opposite direction. Schumpeter (1911) contended that services introduced by financial intermediaries, e.g. savings mobilising and resources allocation, are importance for technological innovation and economic growth. McKinnon (1973) and Shaw (1973) debated that financial repression hinders financial development and, hence, economic growth. Endogenous growth theories also stressed the importance of financial development for long-run economic growth via the influence of financial sector services on capital accumulation and technological innovation (Abu-Bader \& Abu-Qarn, 2008; Nyasha, 2014). However, Robinson (1952) debated that the expansion of real economy drives the demand for financial services and products. The feedback (bidirectional causality) hypothesis of Patrick (1966) assumes that the direction of causality changes over the path of economic development. The supply-leading pattern is dominant during the early stages of economic development whereas the demand-following pattern is dominant at advanced stages.

Bank-based financial systems are believed to be better than stock market-based systems in dealing with problems that arose from financial markets imperfections such as information asymmetry, uncertainty, and principal-agent problems. Banks can gather and process information about firms and managers at low cost and, therefore, produce a wide range of information regarding potential debtors, evaluating projects, and monitoring operations of firms. Small-sized corporations that lack standard financial statements are more likely to raise funds through banks. Moreover, these systems are superior to market-based systems in accelerating economic growth due to their ability to encourage long-term investment in the real sector whereas investment in the latter is more likely to be sensitive to equity prices inducing short-term investments. At times of financial distress, close links between banks and business enable firms to avoid bankruptcy. Liquid financial markets, wherein it is easy to sell shares, are likely to induce speculative trading and, thus, myopic investors have less incentives to monitor firms. (Arestis \& Demetriades, 1996; Luintel et al., 2008; Allen, 1990; Elsayed, 2013). Empirical literature confirms that stock markets and banks are complements rather than substitutes in enhancing economic growth (e.g. Demirguc-Kunt \& Levine, 1996b; Elsayed, 2013).

Given that the Egyptian stock market is currently concentrated and dominated by large firms and that bank credit is the main source of external financing of business activities (Abdel-Kader, 2006; Elsayed, 2013), it is of crucial importance to examine the relationship between bank-based financial development (BBFD) and economic growth (EG) in Egypt. It is essential to examine the direction of causality between BBFD and EG due to the policy implications behind the causal flow. The study addresses the following question: Do causal links between EG and BBFD exist in Egypt? If yes, is it stable or time-varying? The paper hypothesizes that there is time-variant bidirectional causality between BBFD (measured as domestic credit to private business sectors divided by nominal GDP) and EG. Using this ratio as a proxy for BBFD is highly recommended by many scholars (e.g. Ak et al., 2016) since it reflects the effectiveness of financial intermediaries in transferring savings to investors. The objective of the current study is to examine the time-varying causal link between EG and BBFD in Egypt over the period 1960-2016, using bootstrap Granger non-causality tests in a rolling window procedure. Unlike other research examining this relationship for Egypt (e.g. Abu-Bader \& Abu-Qarn, 2008; Elsayed, 2013), the current study employs the longest available time series data of variables under consideration and it assumes that the causal links between them are time-variant. Changes in the developmental level and structural changes in the economy, e.g. policies affecting the banking system, are likely to alter the relationship between EG and BBFD across time. Recent research conducted by Balcilar et al. (2010), Ak et al. (2016), Ahmed and Abdelsalam (2017) and Ahmed and Naguib (2018) documented that relationship between economic and financial variables vary across time. Following Ak et al. (2016), the bootstrap approach to Toda-Yamamoto (1995) modified causality test, which does not require foreknowledge of cointegration, is applied. In other word, the residual bootstrap (RB) based modified-LR statistics is employed for the whole sample and then instability tests are executed. If structural breaks are detected, then the RB-based modified-LR statistics is applied in a rolling window procedure of a fixed size to analyze the time-varying causal relations between the two variables. The RB based modified-LR statistics is more robust compared to other standard asymptotic Granger non-causality tests. Empirical findings revealed that the relationship between EG and BBFD is subject to structural breaks and there exist bidirectional causality that varies across time. The existence of bidirectional causality for Egypt, however static, is confirmed by other researchers (e.g. Elsayed, 2013). The positive effect of output growth on bank credit to both government and private sector in Egypt has been confirmed by (Shetta \& Kamaly, 2014). Moreover, conclusions of (Bolbol et al., 2005) confirmed to that BBFD (measured as the ratio of private credit to GDP) had a positive influence on growth in Egypt. 
The paper proceeds as follows: Section 2 introduces an overview of macroeconomic performance, economic growth and development of the banking system in Egypt during the study period. Section 3 provides a brief review of some studies investigating the link between BBFD and EG. Section 4 presents the time-varying bootstrap methodology and data whereas Section 5 discusses the empirical findings. Finally, Section 6 concludes and offers some policy implications.

\section{Economic Growth, Macroeconomic Performance and Banking System in Egypt: An Overview}

Before the adoption of the ERSAP in Egypt by in 1990s, massive financial repression measures (e.g. administrative control on deposit and lending rates and state ownership of banks) hindered the operation of financial intermediaries. Until the mid-1960s, growth rate reached $6.4 \%$ on average due increasing investments financed by large inflows of foreign aid. Domestic credit to the private sector declined during mid-1960s to 1973 due to credit ceilings and high reserve requirements imposed upon commercial banks by the CBE. The EG sharply declined to around $2.9 \%$ during the same period because of declining savings and investments resulted from, inter alia, the loss of Suez Canal revenues, the increased military expenditure, dominance of public enterprises with low productivity. The open-door policy adopted in 1974 aimed to attract foreign investments and to accelerate economic growth. There was a significant rise in private and foreign investment, however; the smallest proportion was directed towards the industry sector. A banking law number 120 of 1975 was issued to serve this new policy through authorizing the launch of private and joint venture banks, offshore institutions, and foreign bank branches, wherein the condition of under the no-less-than $51 \%$ national ownership had to be met. The number of operating banks rose rapidly to 81 banks in 1991 compared to 7 banks in 1974. Yet, the banking system suffered from lack of competition and innovation. Financial intermediation services and capital allocation provided by the state-owned banks were inefficient and, thus, their balance sheets heavily suffered from the NPLs. Lending was under effective control of the CBE. Relatively-large business obtained the large proportion of the remaining credit which was left to the discretion of banks. Small and medium-sized enterprises (SMEs) had difficulties in obtaining credit because of collateral and lack of information. There was a gradual increase of lending to the private sector from an annual average of 19\% of the GDP during 1941-1974 to around 28\% during 1975-1990 (Mohieldin, 2000; El-Shazly, 2001; Mohieldin \& Nasr, 2003; Bolbola et al., 2005; Abu-Bader \& Abu-Bader, 2008; Daradkah \& Miani, 2011; Elsayed, 2013).

The economy experienced an average growth rate of $8 \%$ during mid-1970s to mid-1980s due to sharp increase in revenues from the Suez Canal, oil exports, tourism and remittances from Egyptians abroad. The structure of the internal economy, however, was still dominated by import substitution and public enterprise. Government expenditures grew faster than its revenues causing sharp fiscal deficit and the economy also suffered from the Dutch disease effect and high inflation rate of around 15\%. Adverse external shocks (i.e. the oil prices collapse and the world recession) hitting the economy during 1986-1991 affected its main sources of foreign currencies. Sluggishness of exports and huge current account revealed the inability of Egypt to serve its external debt which reached $151 \%$ of GDP in 1990/1991. Inflation rate reached 21\% in the same year. Signing the ERSAP with the IMF and the WB in 1991 was accompanied by some favourable external events (e.g. forgiveness of all its debt to the Gulf Countries) which encouraged Egypt to implement comprehensive reforms. During 1991-1998, average growth rate reached $4.6 \%$ and around one third of state-owned enterprises were privatized. Establishing a free market of foreign exchange and easing of capital account controls resulted in eliminating real exchange rate misalignment and the black-market premium. Devaluation of the EGP significantly improved the current account position and led to swift accumulation of foreign reserves. CPI Inflation rate declined to 2.4\% in 2000/2001. Using exchange rate as a nominal anchor, by pegging the EGP to the U.S. dollar, succeeded in keeping inflation rate at low single-digit level and achieving a real appreciation of the EGP of 40\% during 1991/92-1999/2000 (Dobronogov \& Iqbal, 2005; Bolbola et al., 2005; Alba, Al-Shawarby \& Iqbal, 2004; Noureldin, 2008; Alsayed, 2015). Banking reform was an important component of the ERSAP. Reforms included, inter alia, liberalizing deposit and lending rates, removing ceilings imposed on bank-lending to the private sector, permitting $100 \%$ foreign ownership of banks to allow foreign banks to operate in Egypt to enhance competition, and allowing privatization of publicly-owned banks according to Law no. 155 of 1998. Hence, real interest rate finally turned positive. The share of foreign banks in total banks in Egypt jumped from 3\% in 1995 to 20\% in 2000, and the ratio of the credit to the private sector to GDP steadily increased from $22 \%$ in 1991 to $54.5 \%$ in 2001. After floating the EGP in January 2003, banks particularly public ones suffered from high ratios of NPLs. In 2004, the CBE established a NPLs monitoring unit to restructure the publicly-owned banks and privatize some of them, resolve NPLs, support the supervisory authority of the CBE, and consolidate banking systems via acquisitions and mergers of small and weak banks. The number of banks operating in Egypt declined to 39 banks in 2009, with a network of 3504 branches of which 2096 branches were for public-sector banks, due to bank mergers and 
acquisitions. Furthermore, special courts have been set up to accelerate resolution of cases that involve contractual defaults and financial disputes. An institutional framework has been upgraded and modernized by the CBE via the introduction of real time settlement and an automated clearing house (Bolbola et al., 2005; Abu-Bader \& Abu-Qarn, 2008; Poshakwale \& Qian, 2011; Daradkah \& Miani, 2011; Jreisat \& Hassan, 2016; Ahmed, 2017).

The economy sluggishly grew during 1999-2003 due to a series of external shocks including the East Asian Financial Crisis, oil prices drop in 1998, the global turmoil following the attacks of September 2001, and the invasion of Iraq in 2003. Egypt responded to these shocks through an expansionary fiscal policy which resulted in increasing the budget deficits from 3.9\% of GDP in 1999/2000 to an average of 6.1\% in 2002/2003. Pegging the domestic currency weakened Egypt's competitiveness and put pressures on the exchange market since the parallel market was reactivated. The government floated the EGP in January 2003 and, thus, significant correction to the real exchange rate eliminated the misalignment from its equilibrium value. By 2002/2003, the cumulative depreciation of the EGP recorded 31\% resulting in CPI inflation rate climbing to 10.3\% in 2003/2004. Other factors contributed to this jump in inflation rate included energy prices increase and the avian flu virus epidemic. The public deficit reached 9.2\% of GDP on average during 2001/2002-2006/2007, with domestic public debt reaching $93.1 \%$ of GDP in 2006/2007. It was mainly financed from the domestic banking system in the form of T-bills and government bonds. Thus, private credit was crowded out and decreased from $49.6 \%$ to $35 \%$ of GDP during 2001/2002-2006/2007 (Alba, Al-Shawarby, \& Iqbal, 2004; Dobronogov \& Iqbal, 2005; Noureldin, 2008; Helmy, 2008). Starting from 2008, adverse global and country-specific shocks (e.g. the global financial crash in 2008 and the waves of political tensions accompanying the January revolution in 2011) hit the Egyptian economy. These adverse effects included, inter alia, sluggish growth rate, high inflation rate, sharp depreciation of the EGP, shrank of international reserves to critical levels. The real GDP growth at factor cost dropped to $1.7 \%$ during the first quarter of $2016 / 2017$ compared to $3.1 \%$ in the corresponding quarter a year earlier. International reserves dropped from US $\$ 26.4$ billion in June 2011 to $\$ 15.4$ billion in January 2015 (covering 2.8 months of imports). To defend the EGP, the CBE introduced a new system for trading foreign currency, in December 2012, which aimed to conserving its foreign reserves. The EGP sharply fell to an eight-year low against the US dollar to reach EGP 6.70/US\$1 in March 2013. Further depreciation occurred in early 2015 when the CBE announced that the dollar was equivalent to EGP 7.61. To suppress distortions in the foreign exchange market, the CBE announced the floatation of the EGP in November 2016 causing it to depreciate by $45 \%$ and it was, again, depreciated by $38.4 \%$ by early 2017 , resulting in a significant hike in inflation. The public deficit, mainly financed from domestic sources, rose from $6.8 \%$ of GDP in 2008 to $12.3 \%$ in 2015/2016. The credit to private business sector declined from $33.1 \%$ of total credit in June 2012 to $20.4 \%$ in June 2016 whereas the banks' holdings of government securities increased from $65.9 \%$ of total credit to $67.3 \%$ during the same period (Herrera \& Youssef, 2013; CBE, 2016; Zaki et al., 2017; Helmy \& Zaki, 2017; Ahmed \& Naguib, 2018; ECES, 2017).

\section{Bank-Based Financial Development and Economic Growth: A Brief Review}

The literature investigating the relationship between bank-based finance and economic growth is voluminous and it is infeasible trying to cover it. Thus, the current section introduces a brief review of some recent studies that investigated the relationship between EG and BBFD. The debate regarding the complementarity or substitutability of bank-based and market-based financial development in enhancing economic growth and the selection of BBFD indicators is out of the scope of the current review. Research examining BBFD and EG nexus could be classified into three groups (for a recent survey, see Nyasha \& Odhiambo, 2014). The first group supports the finance-led growth hypothesis (Demirguc-Kunt \& Levine, 1996a, 1996b; King \& Levine, 1993a, 1993b; Arestis \& Demetriades, 1996; Elsayed, 2013; Khalifa Al-Yousif, 2002; Christopoulos \& Tsionas, 2004; Barajas et al., 2013). For example, Khalifa Al-Yousif (2002) examined the relationship between BBFD and EG in 30 developing countries including Egypt during the period 1970-1999. For Egypt, no causality was detected when using the ratio of currency to narrow money whereas financial development and EG were found to be determined jointly in the long-run when using monetization ratio. Using an ARDL model for the Egyptian data over the period 1967-1996, Hussain (1997) found that BBFD (measured as the ratio of private credit to the total credit) led EG (real GDP per capita). This conclusion confirms to that of (Bolbol et al., 2005) who found that BBFD (measured as the ratio of private credit to GDP) had a positive influence on total factor productivity growth at higher levels of GDP per capita. Furthermore, Ak et al. (2016) detected a unidirectional causality from BBFD, represented by the ratio of domestic credit provided to private enterprises to GDP, to EG in Turkey over the period 1960-2013; however, this causality was time-varying.

Studies under the second group (e.g. Odhiambo, 2004; Rachdi \& Mbarek, 2011) concluded that EG spurs the 
development of the bank-based financial sector. For example, Odhiambo (2004) concluded that EG in South Africa led the development of the banking sector. Using panel data cointegration analysis for six countries of OECD region and four countries from the Middle East and North Africa (MENA) region over the period 1990-2006, Rachdi and Mbarek (2011) confirmed a long-term relationship between BBFD and EG for the OECD and the MENA countries. Moreover, unidirectional causality from EG to BBFD was detected for the MENA countries. Research under the third group (e.g. Abu-Bader \& Abu-Qarn, 2008; Odhiambo; 2011) found bidirectional causality between BBFD and EG. Using the Johansen co-integration and vector error-correction framework, results of Abu-Bader and Abu-Qarn (2008) revealed the existence of long-run equilibrium relationship between BBFD indicators (including the ratio of bank credit to the private sector to GDP) and EG in Egypt during the period 1960-2001. Moreover, Granger causality showed bi-directional causality between BBFD and EG. In line with that, Elsayed (2013) used a Vector Error Correction Model to explore the finance-growth nexus and the pattern of causality for Egypt during the period 1980-2011. Long run findings supported the demand-following hypothesis. Moreover, the causality pattern showed a bidirectional relationship between banking sector development and stock market development and, thus, they were found to be complementary rather than substitutes in Egypt. To sum up and according to the survey conducted by (Nyasha \& Odhiambo, 2014), the relationship between EG and BBFD varies depending on, inter alia, the proxy employed to measure the level of bank financial development; the level of development of the sample countries; data sets; and the methodology used.

Studies employing cross-section data (e.g. Demirguc-Kunt \& Levine, 1996a, 1996b; King \& Levine, 1993a, 1993b) have been criticized since they may be subject to the endogeneity problem and the variation of country specific effects (e.g. financial policies, liberalization and regulations) and, hence, are likely to influence the direction of causality (Arestis \& Demetriades, 1996; Elsayed, 2013). Moreover, panel studies have received criticism since most of them specified a single equation to model the relationship between finance and growth assuming that finance lead the EG, and thereby, this misspecification results in biased estimators. Moreover, averaging the data periods over few years hides important features of the path of economic growth and eliminates any dynamic changes (Elsayed, 2013). Thus, time series approaches that consider an individual country's specificity enable researchers to examine the causality pattern. The current study uses the most recent techniques applied by Ak et al. (2016) to examine the causal links between BBFD and EG in Egypt over the period 1960-2016.

\section{Econometric Methodology}

To examine the existence of causality between BBFD and EG, the RB-based modified-LR statistics is employed. Many scholars (e.g. Balcilar et al., 2010) have documented the robustness of the RB-based modified-LR statistics over other standard asymptotic Granger non-causality tests, regardless of integration properties, sample sizes, and error term processes (homoscedastic or ARCH). Consider the following bivariate VAR(p) process:

$$
y_{t}=\alpha_{0}+\alpha_{1} y_{t-1}+\cdots+\alpha_{p} y_{t-p}+\epsilon_{t} \quad t=1,2, \ldots, T
$$

where $\epsilon_{t}=\left(\epsilon_{1 t}, \epsilon_{2 t}\right)^{\prime}$ is a zero mean IID process with non-singular covariance matrix $\Sigma$ and p is the order of the process which is determined according to the Akaike Information Criterion (AIC). If $\mathrm{y}_{\mathrm{t}}=\left(y_{L D C}, y_{L G D P}\right)^{\prime}$ is divided into sub-vectors, $y_{L D C}$ and $y_{L G D P}$, Equation (1) can be re-written in the following form.

$$
\left[\begin{array}{c}
y_{L D C, t} \\
y_{L G D P, t}
\end{array}\right]=\left[\begin{array}{l}
\alpha_{10} \\
\alpha_{20}
\end{array}\right]+\left[\begin{array}{ll}
\alpha_{11}(L) & \alpha_{12}(L) \\
\alpha_{21}(L) & \alpha_{22}(L)
\end{array}\right]\left[\begin{array}{c}
y_{L G D P, t} \\
y_{L D C, t}
\end{array}\right]+\left[\begin{array}{l}
\epsilon_{1 t} \\
\epsilon_{2 t}
\end{array}\right]
$$

where $y_{L D C, t}$ and $y_{L G D P, t}$ represent the natural logarithm of domestic credit provided to private sector to GDP ratio and the natural logarithm of real gross domestic product, respectively. $\alpha_{i j}(L)=\sum_{k=}^{p} \alpha_{i j, k} L^{k}, i, j=1,2$ and $\mathrm{L}$ is the lag operator defined as $L^{k} X_{t}=X_{t-k}$. The null hypothesis that LGDP does not Granger-cause LDC is tested by imposing the restrictions $\alpha_{12, i}=0$ for $i=1,2, \ldots p$. Similarly, the null hypothesis that LDC does not Granger-cause LGDP is tested by imposing the restriction $\alpha_{21, i}=0$ for $i=1,2, \ldots$. However, the existence of regime shifts, or structural breaks make inferences of full-sample causality invalid (Balcilar et al., 2010). For this reason, the Sup-LR, Mean-LR and Exp- LR parameter stability tests, introduced by Andrews (1993) and Andrews and Ploberger (1994) based on the sequence of Lagrange multiplier statistics, are employed. The rolling window procedure, using a fixed-size moving window, will be implemented in case of detecting parameter instabilities. The rolling window procedure is adopted through dropping the first observation in the window, moving forward and adding a new observation. For each sub-sample, the RB-based modified-LR test can be performed employing a large number of replications to achieve accuracy of the results. The time-varying causality between the LGDP and LDC can be detected by calculating the bootstrap $p$-values of these estimations (Balcilar et al., 2010). The window size is set to be 15 years. An important feature of the bootstrap method is its 
ability to improve the accuracy of estimates by increasing the number of repetitions when the size of the window is small.

\section{Data, Empirical Results, and Discussion}

Annual data of real gross domestic product (GDP) (measured in domestic currency) and the domestic credit provided to private business sector to GDP ratio, covering the period extends from 1960 to 2016, is employed. The data have been collected from the World Bank's database. The private sector credit to GDP ratio reflects the efficiency of banking sector in channeling the savings into credit used by private sector. This measure excludes credit to public sector and credit issued by the CBE and, thus, it measures the effectiveness of financial intermediaries in transferring savings to investors. Hence, it is more closely related with the impact of financial development on investment and economic development than other measures (Ak et al., 2016). Both variables are transformed into natural logarithms. LDC and LGDP stand for the natural logarithm of domestic credit provided to private business sector to GDP ratio and for the natural logarithm of real gross domestic product, respectively. The plot of these variables is shown in Fig. 1. To explore the dynamic linkages between financial development and economic growth series, we first test for a unit root in LDC and LGDP series using the nonparametric $Z_{\alpha}$ test of Phillips (1987) and Phillips and Perron (1988) and its modified version $M Z_{\alpha}$ test of $\mathrm{Ng}$ and Perron (2001). The $M Z_{\alpha}$ test, a modification version of the nonparametric test statistic $Z_{\alpha}$, is more powerful and has smaller size distortion than other unit root tests. Results of unit root tests (which are not reported to save space), reveal that each series is individually integrated of order one. Thus, we proceed to test whether they are cointegrated using the Johansen-Juselius (1990) cointegration test. To determine the optimal lag length, the VAR model has been created for identifying number of lags to be used in co-integrity test. To determine the optimal lag length, the sequential modified likelihood ratio (LR) test statistic, the multivariate Akaike information criterion (MAIC), the multivariate Schwarz information criterion (MSIC), and the multivariate Hannan-Quinn information criterion (MHQIC) are employed. The LR test statistic selects five lags whereas other criteria select two lags. Thus, a VAR(2) model is estimated, however, its residuals are not free from autocorrelation. Accordingly, the model is re-estimated using five lags and residuals are found serially uncorrelated and, therefore, VAR(5) is employed. Results of the cointegration test, in which it has intercept (no trend) in cointegration equation and test VAR, revealed the absence of co-integration relationship (they are not reported to save space). These findings are not in line with that of Elayed (2013) who detected a cointegrating relationship between financial development and growth in Egypt during 1980-2011. Hence, we test for the presence of causality between the variables under concern using a first-differenced VAR model. A VAR model with two lags is found adequate to capture the dynamics of the data since residuals are free from autocorrelation and all roots of characteristic polynomial lie inside the unit circle. A significant unidirectional causality runs from LDC to LGDP is detected implying the support of supply-leading hypothesis (see Table 1).

The bootstrap approach to Toda-Yamamoto (1995) modified causality test has been applied onto the levels of series under examination using the full-sample data where the number of bootstrap replication is set to 2000 (results are shown in Table 2). From Table 2, a bidirectional causality is detected which supports both finance-led growth and growth-led finance hypotheses. Changes in the developmental level and policies affecting the banking system are likely to alter the relationship between EG and BBFD across time. Thus, it is reasonable to test for parameter instability. Given that parameter instability can occur in different ways, we employ several tests, namely Sup-LR, Mean-LR, Exp-LR tests. The null hypothesis of these tests is the same, however; their alternative hypotheses are different. The Sup-LR test is the appropriate in testing for a swift regime shift whereas Mean-LR and Exp-LR tests are both optimal for testing the gradual stability of the model over time and assume that parameters follow a Martingale process (Andrews \& Ploberger, 1994). 


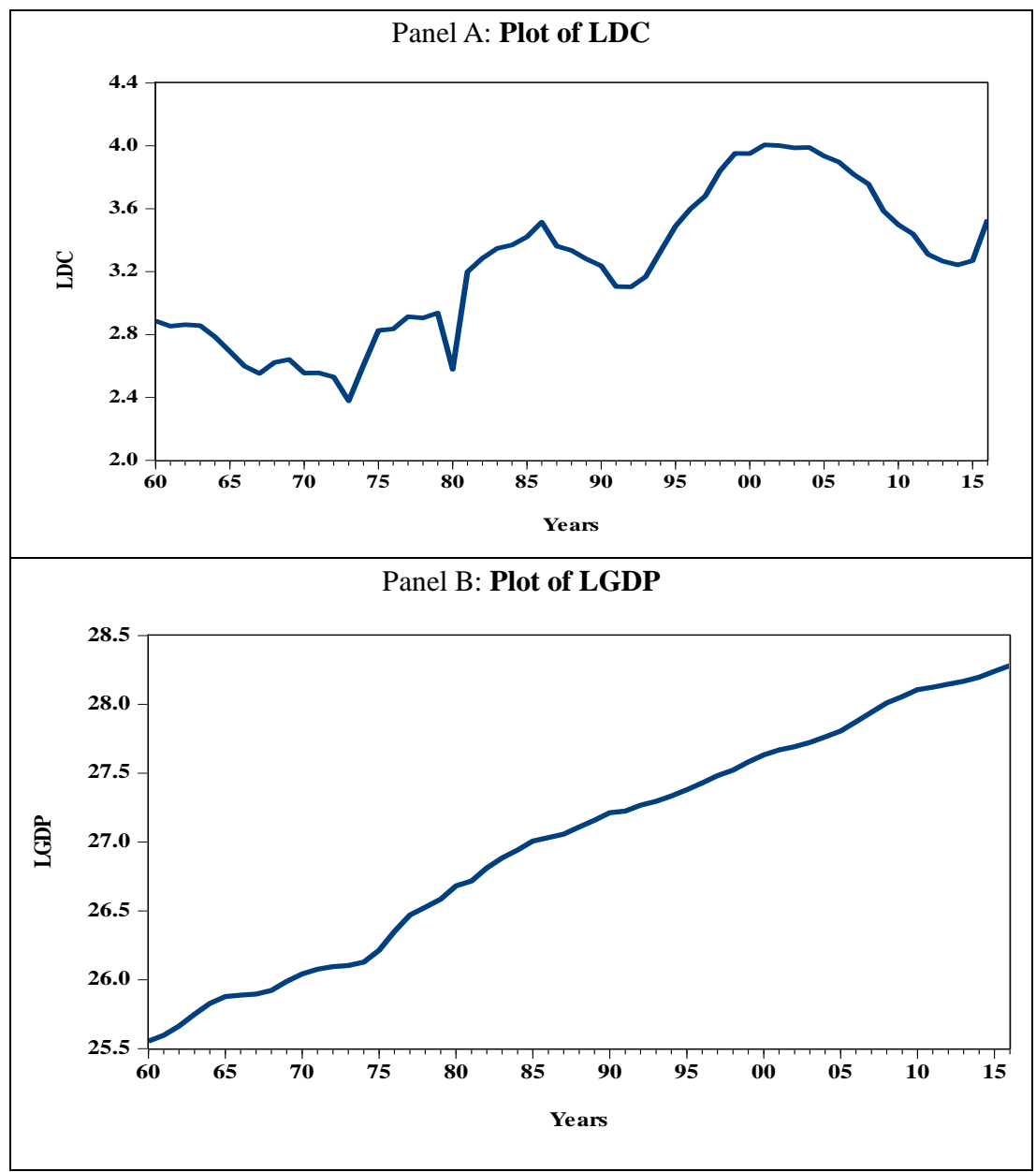

Figure 1. Plot of LDC and LGDP from 1960 to 2016

Table 1. Standard Granger causality tests: results for the full-sample

\begin{tabular}{lcc}
\hline Null Hypothesis & \multicolumn{2}{c}{ Chi-square Test } \\
\cline { 2 - 3 } & Test Statistic & $\boldsymbol{p}$-value \\
\hline$\Delta$ LDC does not Granger cause $\Delta$ LGDP & $20.389 *$ & 0.000 \\
$\Delta$ LGDP does not Granger Cause $\Delta$ LDC & 1.507 & 0.470 \\
\hline
\end{tabular}

Note. * indicates that the null hypothesis of no Granger causality has to be rejected beyond $1 \%$ level of significance.

Source: Author's calculation.

Table 2. Full sample bootstrap Toda -Yamamoto modified causality tests between employed variables

\begin{tabular}{lll}
\hline Null Hypothesis & \multicolumn{2}{c}{ LR Test } \\
\cline { 2 - 3 } & Test Statistic & Bootstrap $\boldsymbol{p}$-value \\
\hline LDC does not Granger cause LGDP & $9.132^{*}$ & 0.045 \\
LGDP does not Granger Cause LDC & $9.127^{*}$ & 0.026 \\
\hline
\end{tabular}

Note. $*$ reject the null hypothesis at $5 \%$, level of significance.

Source: Author's calculations 
Table 3. Parameter stability tests

\begin{tabular}{lcccc}
\hline \multirow{2}{*}{ Test } & \multicolumn{2}{c}{ LDC equation } & \multicolumn{2}{c}{ LGDP equation } \\
\cline { 2 - 5 } & Statistic & Bootstrap $p$-value & Statistic & Bootstrap $p$-value \\
\hline Sup- $L R$ & 9.625 & $0.004^{*}$ & 6.552 & 0.231 \\
Mean- $L R$ & 4.782 & $0.042^{* *}$ & 3.235 & $0.003^{*}$ \\
Exp-LR & 5.965 & $0.009^{*}$ & 11.999 & $0.000^{*}$ \\
\hline
\end{tabular}

Note. *, ** denote rejection of the null hypothesis at $1 \%$ and $5 \%$ respectively.

Source: Author's calculation

Table 3 shows the results of the parameter constancy tests that investigate the stability of the coefficients of the VAR model. The critical values of Sup-LR, Mean-LR, and Exp-LR statistics and their corresponding $p$-values are obtained using a bootstrap approximation to the null distribution, constructed by employing Monte Carlo simulation with 2000 samples generated from a VAR model with constant parameters. These stability tests require trimming at the ends of the sample. As recommended by Andrews (1993), 15\% from both ends are trimmed and tests are calculated for the fraction of the sample in [0.15. 0.85]. According to the Sup-LR statistic in Table 3, the LDC equation experienced a swift regime shift but the LGDP equation did not. The Mean-LR and Exp-LR indicate that the LDC and LGDP equations are likely to evolve gradually over time. Thus, conclusions drawn using full sample are not reliable. Following Ak et al. (2016), the VAR model in Equation 2 is re-estimated using rolling window procedure for a time span of 15 year. For each sub-sample, the RB $p$-values of the modified LR-statistics that tests the absence of Granger-causality from LGDP to LDC or vice-versa are calculated.

Panels A, B, C and D in Figure 2 show the rolling bootstrap of $p$-values of LR-statistics using LGDP and LDC as dependent variables, bootstrap estimates of the sum of the rolling window coefficients for the impact of LGDP on LDC and vice versa, respectively. In each panel, the horizontal axis shows the final observation in each of the 15-year rolling windows. The horizontal axis in Panels A and B represents the $10 \%$ level of significance. The impact of EG on BBFD is calculated as the mean of the all bootstrap estimates, that is $N_{b}^{-1} \sum_{k=1}^{p} \hat{\alpha}^{*}{ }_{21, k}$. Analogously, the influence of BBFD on EG is calculated as $N_{b}^{-1} \sum_{k=1}^{p} \hat{\alpha}^{*}{ }_{12, k}$. These are calculated through rolling the whole sample with a fixed window size of 15 years. $\hat{\alpha}^{*}{ }_{21, k}$ and $\hat{\alpha}^{*}{ }_{12, k}$ are the bootstrap least squares estimates from the VAR in equation (2). Moreover, the $95 \%$ confidence intervals are also computed, where the lower and upper limits are obtained as the 2.5th and 97.5th quantiles of each of $\hat{\alpha}^{*}{ }_{21, k}$ and $\hat{\alpha}^{*}{ }_{12, k}$, respectively.

According to Panels A and B of Figure no. 2, there exist time-varying bidirectional causality between BBFD and EG in Egypt during the period 1960-2016. However, no causality is detected in either direction up to 1990. The BBFD seems not to have a predictive power of EG (see Panel C) and, similarly, EG does not have a predictive power for BBFD (see Panel D) since the mean of the all bootstrap estimates is close to zero during the period 1960-1990. The absence of causality in either direction until 1990 is not surprising since, as mentioned in Section 2, high growth rates until the mid-1960s was mainly financed by large inflows of foreign aid whereas rapid economic growth over the period mid-1970s to mid-1980s was driven by sharp increase in revenues from the Suez Canal, oil exports, tourism and remittances from Egyptians working in oil-exporting Gulf countries. Moreover, financial system was subject to massive financial repression measures that hindered the operation of financial intermediaries before the adoption of the ERSAP in early 1990s. The bank credit significantly increased from an annual average of 54\% of GDP during the period 1961-1974 to 97\% during the 1975-1990. Funds were still mainly channeled to the public sector, however; there was a gradual increase of lending to the private sector from an annual average of $19 \%$ GDP to around $28 \%$ during the aforementioned periods respectively. Under financial repression, lending criteria included client reputation, loan size, and political pressures. SMEs had difficulties in obtaining credit because of collateral and lack of information (Mohieldin, 2000; Bolbola et al., 2005; Elsayed, 2013). Panels A and B of Figure 2 display that feedback causality between the two series under examination exists during sub-samples extending from 1991 to 2009 whereas Panels C and D of the same figure confirm that each variable has a positive effect on the other variable. Thus, both supply-led and demand-led hypotheses are valid for Egypt during this period since development of real sector drives the demand for financial services and introducing these services is essential for economic growth. Important reforms of the banking sector took place since the adoption of the ERSAP in early 1990s. These reforms included the removal of ceilings on bank-lending to the private sector in October 1992 and shifting towards the adoption of indirect monetary instruments wherein the CBE introduced weekly auctions of treasury bills to mobilize savings and generate a market mechanism for determination of interest rate. Moreover, the introduction of longer maturity bills contributed to regulate banks' reserves and thus credit expansion. Credit provided to private business sector as a share of GDP constantly increased from around 22\% in 1991 to $55 \%$ by the end of 2002 and, thus, Egypt 
was put closer to the private credit ratio in low and middle-income countries (Bolbola et al., 2005; Elsayed, 2013). Regarding the sub-periods that witnessed global financial crisis and country-specific shocks (i.e. political instability), 2000-2014, 2001-2015, and 2002-2016, the null hypothesis of no causality from LGDP to LDC or vice-versa could not be marginally rejected since the RB $p$-values of the modified LR-statistics just exceeded the $10 \%$ level of significance (see panels A and B of Figure 2). This is reflected in the sum of rolling coefficients being close to zero (Panels C and D of Figure 2).

Average yearly growth rate of credit provided to private business sector declined from 24\% during 1995-1999 to $8.3 \%$ over the period 2000-2005. The percent of NPLs to total loans increased from around $15 \%$ in 2000 to $26 \%$ in 2005. During the period 1995-1999, credit was lent to businessmen without a rational assessment of risk or prediction of the feasibility of the projects they were investing in. A large proportion of credit was directed to real estate business with rapid growth and high profit margins at the end of the 1990's. However, many businessmen went into default unable to repay to banks due to excessive supply and the worldwide recession and, therefore, they escaped from Egypt. Many top-banking officials have been prosecuted of abusing their positions by giving credit to businesspersons without applying appropriate credit criteria and thus, these bankers were sentenced and sent to jail. (Mohieldin \& Nasr 2003; Abdel-Kader, 2006; Alsayed, 2015; Ahmed, 2017). Abdel-Kader (2006) concluded that Egypt experienced credit crunch during the crisis of NPLs which was aggravated by asymmetric information due to the absence of a nationwide credit rating system, which led to an "adverse selection" problem. Thus, banks became more risk-averse and, thus, they reduced credit to private sector and preferred to invest in more liquid and less risky assets such as treasury bills and government bonds. However, the ratio of NPLs to total loans declined in recent years (it reached around 10\% in 2011), it was because of credit constraints rather than enhancing the efficiency of credit supply process. Compared to low and middle-income courtiers wherein this ratio is around 3.3\%, the Egyptian banks' balance sheets were still poor and heavily strained with high NPLs (Elsayed, 2013). Starting from 2004, both loans to assets and loans to deposits ratios have declined significantly indicating deterioration in overall banks' intermediation function. Moreover, access to bank financial services is weak where the number of bank branches and automated teller machines (ATMs) per capita is less than in countries with similar per capita income. Relative to the developing world, Egypt's branch density is low, and its ATM coverage is less than one-seventh that of a typical developing country (Nasr, 2006; Reda, 2012; Ahmed, 2017)

The ratio of the private credit to GDP continually decreased during the period 2004-2016 (see Panel A of Figure 1). Moreover, the credit to private business sector declined from $33.1 \%$ of total credit in June 2012 to $20.4 \%$ in June 2016, as mentioned earlier. This could be explained by the crowding out effect of credit expansion to the government as the main reason. For example, Herrera and Youssef (2013) showed that the increase of commercial bank credit to the government during the recent capital outflow episode starting from 2011 was accompanied by an accelerated decline in the fraction of credit to the private sector. They found that the economic slowdown accounts for around 15 to $20 \%$ of the predicted total fall in credit whereas the expansion of credit to the government accounts for the remaining fraction. Additionally, Shetta and Kamaly (2014) confirmed the validity of lazy bank hypothesis in Egypt where banks shift their portfolio away from risky private loans and opt for lazy behaviour characterized by a shrinking overall credit tilted more and more toward government debt-instruments. Pressing forward with banking reform plan starting from 2009, the CBE focused on several pillars including applying Basel II standards in the Egyptian banks with the aim of enhancing risk management practices and adopting an initiative promoting the development and growth of banking services and access to finance for various sectors, especially SMEs. However, lending to SMEs remained limited. Main obstacles facing the SMEs financing include the poor access to adequate, timely and reliable statistical data and information (Nasr, 2006; Reda, 2012; Elsayed, 2013). 
Panel (A): Bootstrap p-values of LR test statistic testing the null hypothesis that LDC does not Granger-cause LGDP

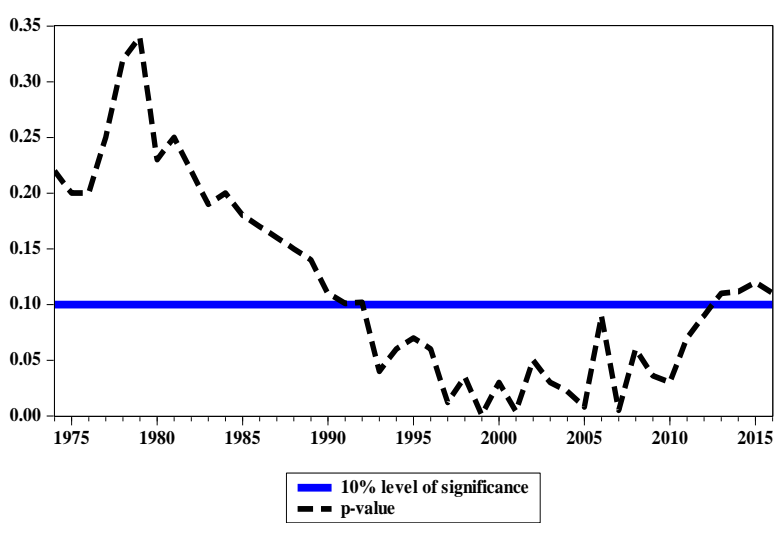

Panel (C): Bootstrap estimate of the sum of the rolling coefficients for the impact of LDC on LGDP

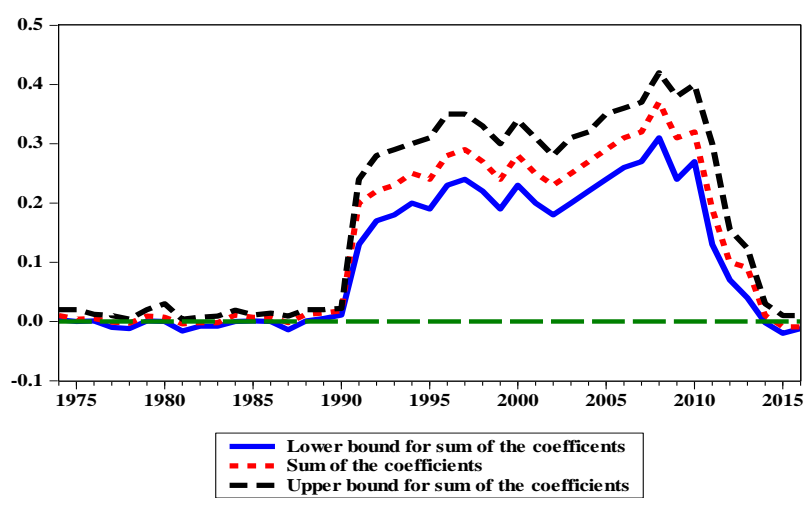

Panel (B): Bootstrap p-values of LR test statistic testing the null hypothesis that LGDP does not Granger-Cause LDC

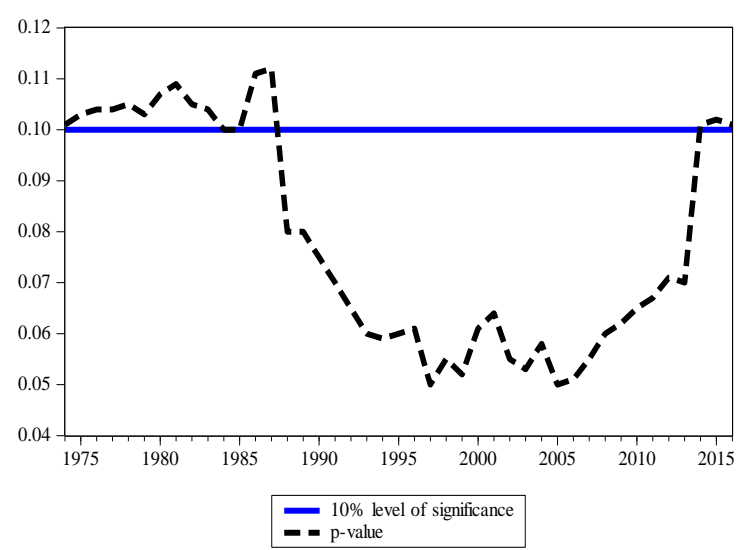

Panel (D): Bootstrap estimate of the sum of the rolling coefficients

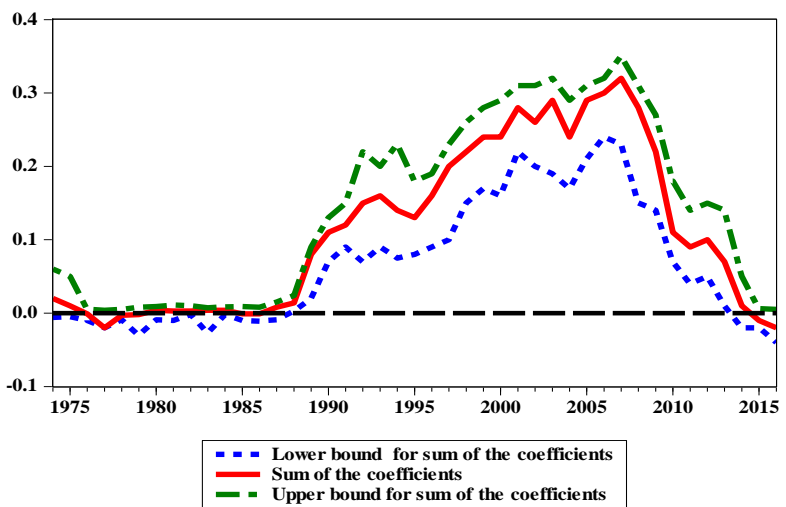

Figure 2. Results of rolling window estimation

Source: Author's calculations.

\section{Conclusions and Policy Implications}

The current study investigated the time varying causality between BBFD and EG in Egypt over the period 1960-2016. It applied the bootstrap approach to Toda-Yamamoto (1995) modified causality test to the whole sample. Given the misleading inferences made based upon the full sample due to the existence of structural breaks, the aforementioned causality test was executed in a rolling window of fixed size to capture the dynamic causal links between variables under consideration. Findings revealed the existences of time-varying bidirectional causality between BBFD and EG in Egypt over the study period. This is not surprising since the study period witnessed structural changes and reforms in Egypt including the transition from planned economy to an outward-looking open-door policy and then to the adoption of a comprehensive reform program, i.e. the ERSAP. Moreover, it includes elimination of financial repression measures, banking reform, and global and country-specific shocks (e.g. political instability accompanying the January Revolution in 2011). The analysis showed that the declining fraction of credit given to the private business sector to GDP during the recent decades cloud be attributed to crowding out effect of the expansion of credit to the government, factors related to supply of credit (credit crunch), NPLs and the lack of information regarding the quality of borrowers. The recent economic slowdown accounted for a small proportion of the fall in credit provided to the private business sector. To enhance the role of banking system in promoting economic growth, it is important to increase the number of credit bureaus and enhance their roles, handling the problem of NPLs, adopting fiscal reforms, and promoting innovative financial tools and instruments which are well-suited for the needs of SMEs especially in vital economic sectors and activities. Fiscal reforms, including both tax and subsidies reform, are required to set the public debt to GDP ratio on a declining path and reduce the budget deficit. Depressing domestic financing of the budget deficit would crowd in private sector credit and support a deceleration of inflation. In this regard, Helmy and Zaki (2017) recommended the adopting of sound energy pricing mechanism to help alleviate the impact of changes in the oil import bill on the petroleum products subsidy bill that account for a significant percent of 
public expenditure. An important measure to help evaluate the creditworthiness of potential borrowers was taken in August 2005 when the CBE issued rules and procedures for the licensing of credit bureaus. The first credit bureau was established in September 2005 under CBE supervision. Credit bureaus help banks improve their risk management and, hence, reduce the volume of NPLs by sharing information on borrowers. Reda (2012) recommended that improving credit scoring adapted to SMEs would encourage banks to increase lending to SMEs. Also, she suggested that banks could also establish a link between leasing and traditional credit facilities. Establishing a registrar for movable assets is crucial for the protection of leasing activities and to reduce fraud.

\section{References}

Abdel-Kader, K. (2006, July). Private Sector Access to Credit in Egypt: Evidence from Survey Data. The Egyptian Center for Economic Studies, WP No. 111.

Abu-Bader, S., \& Abu-Qarn, A. S. (2008). Financial Development and Economic Growth: The Egyptian Experience. Journal of Policy Modeling, 30, 887-898. https://doi.org/10.1016/j.jpolmod.2007.02.001

Ahmed, A. A. (2017). Performance of the Egyptian Banking Sector During 1991-2014: An Analytical Study. Journal of Business Studies and Research, 37(4). Faculty of Commerce, Benha university.

Ahmed, A. A., \& Naguib, R. I. (2018). DCCs among Sector Indexes and Dynamic Causality between Foreign Exchange and Equity Sector Volatility: Evidence from Egypt. Applied Economics and Finance, 5(1), 14-28. https://doi.org/10.11114/aef.v5i1

Ahmed, D. A., \& Abdelsalam, M. A. M. (2017). Dynamic Causality between Inflation and its Uncertainty. Africa Meeting of the Econometric Society, Algeria, June $29^{\text {th }}-$ July $1^{\text {st }}$.

Ak, M. Z., Kirca, M., \& Altintaş, N. (2016). The impacts of Financial Development on Growth: A Time-varying Causality Analysis for Turkey. Zbornik Radova Ekonomskog Fakulteta u Rijeci, 34(2), 529-554. doi: https://doi.org/10.18045/zbefri.2016.2.529

Alba, P., Al-Shawarby, S., \& Iqbal, F. (2004, May). Fiscal and Public Debt Sustainability in Egypt. The Egyptian Centre for Economic Studies, WP No. 97.

Allen, F. (1990). The Market for Information and The Origin of Financial Intermediation. Journal of Financial Intermediation, 1, 3-30. https://doi.org/10.1016/1042-9573(90)90006-2

Alsayed, M. N. (2015). Economic Reform, Banks' Efficiency and Market Structure in Egypt (Durham theses, Durham University). Retrieved from http://etheses.dur.ac.uk/11133/

Andrews, D. W. K. (1993). Tests for parameter instability and structural change with unknown change point. Econometrica, 61, 821-856. https://doi.org/10.2307/2951764

Andrews, D. W. K., \& Ploberger, W. (1994). Optimal tests when a nuisance parameter is present only under the alternative. Econometrica, 62(6), 1383-1414. https://doi.org/10.2307/2951753

Arestis, P., \& Demetriades, P. O. (1996, May). Finance and Growth: Institutional Considerations and Causality. Department of Economics, WP No.5, University of East London. https://doi.org/10.2139/ssrn.35996

Balcilar, M., Ozdemir, Z. A., \& Arslanturk, Y. (2010). Economic growth and energy consumption causal nexus viewed through a bootstrap rolling window. Energy Economics, 32, 1398-1410. https://doi.org/10.1016/j.eneco.2010.05.015

Bolbola, A. A., Fatheldina, A., \& Omran, M. M. (2005). Financial development, structure, and economic growth: the case of Egypt, 1974-2002. Research in International Business and Finance, 19, 171-194. https://doi.org/10.1016/j.ribaf.2004.10.008

Daradkah, D., \& Miani, S. (2011). Banking Industry in Egypt. Transit Stud Review, 18, 65-84. https://doi.org/10.1007/s11300-011-0192-4

Demirguc-Kunt, A., \& Levine, R. (1996a). Stock Market Development and Financial Intermediaries: Stylized Facts. The World Bank Economic Review, 10, 291. https://doi.org/10.1093/wber/10.2.291

Demirguc-Kunt, A., \& Levine, R. (1996b). Stock Markets, Corporate Finance, and Economic Growth: An Overview. The World Bank Economic Review, 10, 223. https://doi.org/10.1093/wber/10.2.223

Dobronogov, A., \& Iqbal, F. (2005). Economic Growth in Egypt: Constraints and Determinants. Working Paper no. 42, Middle East and North Africa, Social and Economic Development Group, The World Bank. https://doi.org/10.2139/ssrn.872328

ECES. (2017). Egypt's Economic Profile and Statistics. Annual Booklet. Egyptian Centre for Economic Studies, 
Cairo.

Elsayed, A. H. A. (2013). The Relationship between Financial System Development and Economic Growth in the Egyptian Economy. $\mathrm{PhD}$ thesis, Leeds University Business School. Retrieved from http://etheses.whiterose.ac.uk/5506/

El-Shazly, A. (2001). Incentive-Based Regulations and Bank Restructuring in Egypt. Topics in Middle Eastern and African Economies, 3.

Helmy, O. (2008, November). The Impact of Budget Deficit on Inflation in Egypt. WP No. 141, The Egyptian Centre for Economic Studies.

Helmy, O., \& Zaki, C. (2017). The nexus between internal and external macroeconomic imbalances: Evidence from Egypt. Middle East Development Journal. https://doi.org/10.1080/17938120.2017.1368217

Herrera, S., \& Youssef, H. (2013). Macroeconomic Shocks and Banking Sector Developments in Egypt. WP 802, The Economic Research Forum. https://doi.org/10.1596/1813-9450-6314

Hussain, N. M. N. (1997). Financial Liberalization, Currency Substitution and Investment: The Case of Egypt. African Review of Money Finance and Banking, 57-86. Retrieved from https://www.jstor.org/stable/23026380?seq=1\#page_scan_tab_contents

Johansen, S., \& Juselius, K. (1990). Maximum Likelihood Estimation and İnference on Cointegration with Applications to The Demand for Money. Oxford Bulletin of Economics and Statistics, 52(2), 169-210. https://doi.org/10.1111/j.1468-0084.1990.mp52002003.x

Jreisat, A., \& Hassan, H. (2016). Productivity Change of the Egyptian Banking Sector: A Two Stage Non-Parametric Approach. Topics in Middle Eastern and African Economies, 18(1), 145-155.

Jung, W. S. (1986). Financial development and economic growth: International evidence. Economic Development and Cultural Change, 4(2), 333-346. https://doi.org/10.1086/451531

Khalifa Al-Yousif, Y. (2002). Financial Development and Economic Growth: Another look at The Evidence from Developing Countries. Review of Financial Economics, 11, 131-150. https://doi.org/10.1016/S1058-3300(02)00039-3

Luintel, K. B., Khan, M., Arestis, P., \& Theodoridis, K. (2008). Financial Structure and Economic Growth. Journal of Development Economics, 86, 181-200. https://doi.org/10.1016/j.jdeveco.2007.11.006

McKinnon, R. I. (1973). Money and capital in economic development. Washington, DC: Brookings Institution.

Mohieldin, M. (2000, May). On Bank Market Structure and Competition in Egypt. Conference on Financial Development and Competition in Egypt, Cairo, Egypt. Retrieved from http://citeseerx.ist.psu.edu/viewdoc/download?doi=10.1.1.555.8839\&rep=rep1\&type=pdf

Mohieldin, M., \& Nasr, S. (2003, September). Financial Policy in Egypt. Economic Research Forum \& Forum Euro-Mediterraneaeen des Institutes Economiques.

Nasr, S. (2006). Access to finance and economic growth in Egypt. World Bank, Middle East and North African Region, World Bank, Washington, DC. Retrieved from http://siteresources.worldbank.org/INTEGYPT/Resources/Access_to_Finance.pdf

Noureldin, D. (2008, May). Relative Price Adjustment and Inflation Dynamics: The Case of Egypt. WP No. 133, The Egyptian Centre for Economic Studies.

Nyasha, S. (2014). Financial development and economic growth: New evidence from six countries. PhD thesis, University of South Africa. http://hdl.handle.net/10500/18576

Nyasha, S., \& Odhiambo, N. M. (2014). Bank-based Financial Development and Economic Growth: A Review of International Literature. Journal of Financial Economic Policy, 6(2), 112-132. https://doi.org/10.1108/JFEP-07-2013-0031

Patrick, H. T. (1966). Financial development and economic growth in underdeveloped countries. Economic Development and Cultural Change, 14(1), 174-189. https://doi.org/10.1086/450153

Phillips, P. C. (1987). Time series regression with a unit root. Econometrica, 55, $277-302$. https://doi.org/10.2307/1913237

Phillips, P. C., \& Perron, P. (1988). Testing for a unit root in time series regression. Biometrika, 75, $335-346$. https://doi.org/10.2307/2336182 
Poshakwale, S. S., \& Qian, B. (2011). Competitiveness and Efficiency of the Banking Sector and Economic Growth in Egypt. African Development Review, 23(1), 99-120. https://doi.org/10.1111/j.1467-8268.2010.00275.x

Reda, M. (2012, November). Measuring Banking Efficiency Post Consolidation: The Case of Egypt. Egyptian Centre for Economic Studies, WP No. 173.

Robinson, J. (1952). The rate of interest and other essays. London: Macmillan.

Schumpeter, J. A. (1911). The Theory of Economic Development. Cambridge: Harvard University Press.

Shaw, E. S. (1973). Financial deepening in economic development. New York: Oxford University Press

Shetta, S., \& A Kamaly, A. (2014, September). Does the Budget Deficit Crowed-out Private Credit from the Banking Sector? the Case of Egypt. Topics in Middle E astern and African Economies, 16(2), 251-279.

Toda, H. Y., \& Yamamoto, T. (1995). Statistical Inference in Vector Autoregressions with Possibly Integrated Processes. Journal of Econometrics, 66(1), 225-250. https://doi.org/10.1016/0304-4076(94)01616-8

Zaki, C., Ehab, M., \& Abdallah, A. (2017, November). How Do Trade Margins Respond to the Exchange Rate? The Case of Egypt. WP No. 189, The Egyptian Centre for Economic Studies. Retrieved from http://www.eces.org.eg/Publication.aspx?Id=631

\section{Copyrights}

Copyright for this article is retained by the author(s), with first publication rights granted to the journal.

This is an open-access article distributed under the terms and conditions of the Creative Commons Attribution license (http://creativecommons.org/licenses/by/4.0/). 